medRxiv preprint doi: https://doi.org/10.1101/2020.09.29.20201509; this version posted November 19, 2020. The copyright holder for this preprint (which was not certified by peer review) is the author/funder, who has granted medRxiv a license to display the preprint in

All rights reserved. No reuse allowed without permission.

\title{
Laboratory evaluation of SARS-CoV-2 antibodies: detectable IgG up to 20 weeks post infection.
}

Authors: Louise J. Robertson ${ }^{1}$, Julie S. Moore ${ }^{1}$, Kevin Blighe ${ }^{1}$, Kok Yew Ng${ }^{2}$, Nigel Quinn $^{3}$, Fergal Jennings ${ }^{3}$, Gary Warnock ${ }^{4}$, Peter Sharpe ${ }^{3}$, Mark Clarke ${ }^{5}$, Kathryn Maguire $^{5}$, Sharon Rainey ${ }^{5}$, Ruth Price ${ }^{1}$, William Burns ${ }^{2}$, Amanda Kowalczyk ${ }^{1}$, Agnes Awuah $^{1}$, Sara McNamee ${ }^{2}$, Gayle Wallace ${ }^{6}$, David Hunter ${ }^{6}$ Steve Segar $^{1}$, Connie Chao Shern ${ }^{7}$, M. Andrew Nesbit ${ }^{1}$, James McLaughlin ${ }^{2^{*}}$, Tara Moore ${ }^{187^{*}}$.

${ }^{1}$ Biomedical Sciences Research Institute, Ulster University, Northern Ireland ${ }^{2}$ Nanotechnology and Integrated Bioengineering Centre, Ulster University, Northern Ireland

${ }^{3}$ Clinical Biochemistry Laboratory, Southern Health and Social Care Trust, Northern Ireland

${ }^{4}$ Microbiology Laboratory, Southern Health and Social Care Trust, Northern Ireland ${ }^{5}$ Northern Ireland Blood Transfusion Service, Belfast City Hospital, Northern Ireland ${ }^{6}$ Royal Victoria Hospital, Belfast Health and Social Care Trust, Northern Ireland.

${ }^{7}$ Avellino, 1505 Adams Dr, Menlo Park, CA 94025, United States

*Joint corresponding authors- Professor Tara Moore tara.moore@ulster.ac.uk Professor James McLaughlin jad.mclaughlin@ulster.ac.uk 
medRxiv preprint doi: https://doi.org/10.1101/2020.09.29.20201509; this version posted November 19, 2020. The copyright holder for this preprint (which was not certified by peer review) is the author/funder, who has granted medRxiv a license to display the preprint in

36 Abstract

37 Background

38 The SARS-CoV-2 pandemic necessitated rapid and global responses across all areas

39 of healthcare, including an unprecedented interest in serological immunoassays to

40 detect antibodies to the virus. The dynamics of the immune response to SARS-CoV-

412 is still not well understood and requires further investigation into the longevity of

42 humoral immune response that is evoked due to SARS-CoV-2 infection.

43 Methods

44 We measured SARS-CoV-2 antibody levels in plasma samples from 880 people in

45 Northern Ireland using Roche Elecsys Anti-SARS-CoV-2 IgG/lgA/lgM, Abbott SARS-

46 CoV-2 IgG and Eurolmmun IgG SARS-CoV-2 ELISA immunoassays to analyse

47 immune dynamics over time. We undertook a laboratory evaluation for the UK-RTC

48 AbC-19 rapid lateral flow immunoassay (LFIA), for the target condition of SARS-CoV-

492 Spike protein $\lg$ antibodies using a reference standard system to establish a

50 characterised panel of 330 positive and 488 negative SARS-CoV-2 IgG samples.

51 Results

52 We detected persistence of SARS-CoV-2 IgG up to 140 days (20 weeks) post

53 infection, across all three laboratory-controlled immunoassays. On the known positive

54 cohort, the UK-RTC AbC-19 lateral flow immunoassay showed a sensitivity of $97.58 \%$

55 (95.28\%-98.95\%) and on known negatives, showed specificity of $99.59 \%(98.53 \%-$

$5699.95 \%)$.

57 Conclusions

58 Through comprehensive analysis of a cohort of pre-pandemic and pandemic

59 individuals, we show detectable levels of IgG antibodies, lasting up to 140 days,

60 providing insight to antibody levels at later time points post infection. We show good 
medRxiv preprint doi: https://doi.org/10.1101/2020.09.29.20201509; this version posted November 19, 2020. The copyright holder for this preprint (which was not certified by peer review) is the author/funder, who has granted medRxiv a license to display the preprint in All rights reserved. No reuse allowed without permission.

61 laboratory validation performance metrics for the AbC-19 rapid test for SARS-CoV-2

62 Spike protein $\lg G$ antibody detection in a laboratory based setting.

63

64 Keywords

65 SARS-CoV-2, COVID-19, immunoassay, LFIA, pandemic, antibody assay

66

67 Introduction

68 The World Health Organization declared a pandemic in March 2020 due to severe 69 acute respiratory syndrome coronavirus-2 (SARS-CoV-2), identified late 2019 in 70 Wuhan, China, causing COVID-19 disease $(1,2)$.

71 A global race ensued to develop diagnostic assays, with the most common being viral 72 RNA detection (RT-qPCR assays), to detect acute infection(3). RT-qPCR assays are labour and reagent intensive, limited by a short temporal window for positive diagnosis, and exhibit potential for false negative results (4). Evidence suggests sensitivity of RTqPCR can be as low as 70\% (5). Lockdown measures and "flattening the curve" strategies meant many infected individuals were instructed to self-isolate and were not offered a diagnostic RT-qPCR, with much of the testing limited to patients admitted to hospital, who perhaps reflect a more severely infected cohort. Consequently, a potentially large number of cases were unconfirmed or undetected(6).

The ability to accurately detect SARS-CoV-2 specific antibodies, which develop after an immune response is evoked, is vital for building biobanks of convalescent sera for treatment, monitoring immune response to infection alongside surveillance studies and assessing responses to vaccination programmes. The timing for when antibody against the novel SARS-CoV-2 virus can be measured is at this time not fully characterised. 
medRxiv preprint doi: https://doi.org/10.1101/2020.09.29.20201509; this version posted November 19, 2020. The copyright holder for this preprint (which was not certified by peer review) is the author/funder, who has granted medRxiv a license to display the preprint in

All rights reserved. No reuse allowed without permission.

86 Commercial serology immunoassays are mostly laboratory-based and measure IgG

87 antibody levels in plasma or serum. Alternatively, lateral flow immunoassays (LFIAs),

88 require a finger prick blood sample and can be used at point-of-care (POC) or in the

89 home; particularly important in the context of lockdown enforcement during the

90 pandemic. Currently, a limited number of laboratory-based chemiluminescence

91 immunoassays are approved for use in the UK including the Roche Elecsys Anti-

92 SARS-CoV-2 IgG/lgA/lgM against the SARS-CoV-2 Nucleocapsid antigenic region

93 (Roche Diagnostics, Basel, Switzerland) and the Abbott SARS-CoV-2 IgG assay

94 against the same antigenic region (Abbott Diagnostics, Abbott Park, IL, USA).

95 The complexities of the humoral immune response to SARS-CoV-2 is a much-

96 debated topic. In a US study, approximately one in 16 individuals lacked detectable

97 IgG antibodies up to 90 days post symptom onset, despite previous RT-PCR

confirmed infection (7). Patients who remain asymptomatic may mount a humoral

immune response which is short-lived, with detectable levels of antibody falling

100 rapidly (8). This, alongside potentially low sensitivity and lack of RT-PCR test

101 availability across the UK has hindered development of well characterised gold

standard serology test for IgG antibodies to SARS-CoV-2.

103

Herein, we describe the use of Roche and Abbott commercial immunoassays, as well as the Eurolmmun Anti-SARS-CoV-2 ELISA-IgG against the S1 domain of the spike antigenic protein of SARS-CoV-2 (Eurolmmun UK, London, UK) to characterise pre-

106 pandemic and pandemic COVID-19 blood samples $(n=880)$ from within Northern

107 Ireland and report on longevity of $\lg G$ antibodies detected. Presently, there is no gold standard assay for comparison, therefore we aimed to establish a reference based on a positive COVID-19 antibody status. We present results of a laboratory evaluation of

110 the UK-RTC AbC-19 with a target condition of antibodies against a cohort of 330 
medRxiv preprint doi: https://doi.org/10.1101/2020.09.29.20201509; this version posted November 19, 2020. The copyright holder for this preprint (which was not certified by peer review) is the author/funder, who has granted medRxiv a license to display the preprint in All rights reserved. No reuse allowed without permission.

111 known $\lg G$ antibody positive samples according to this 'positive by two' system and

112488 negative samples (223 pre-pandemic assumed negative and 265 known negative)

113 for IgG to SARS-CoV-2.

\section{Methods}

\section{Participant samples}

118 The flow of participant samples is summarised in Figure S1. All participants provided

119 informed consent with no adverse events. An online recruitment strategy was

120 employed, with the study advertised through internal Ulster University email, website

121 and social media. A BBC Newsline feature providing the pandemic study email address also prompted interest from the general population.

124 A small cohort $(n=19)$ of anonymised plasma samples were obtained from a partner

125 USA laboratory for initial protocol development only. The first 800 respondents who 126 expressed interest were provided with an online patient information sheet, consent

127 form and health questionnaire and invited to register to attend a clinic. Exclusion 128 criteria related to blood disorder or contraindication to giving a blood sample. To enrich

129 the cohort for samples potentially positive for SARS-CoV-2 IgG antibody, further

130 participants were invited if they had previously tested PCR positive or had the

131 distinctive symptom of loss of taste and smell. Blood sampling clinics were held at

132 locations around Northern Ireland between April and July 2020 resulting in collection

133 of $26310 \mathrm{ml}$ EDTA plasma samples from 263 separate study participants. Additional

134 anonymised plasma samples were obtained from Southern Health and Social Care 
medRxiv preprint doi: https://doi.org/10.1101/2020.09.29.20201509; this version posted November 19, 2020. The copyright holder for this preprint (which was not certified by peer review) is the author/funder, who has granted medRxiv a license to display the preprint in All rights reserved. No reuse allowed without permission.

135 Trust (SHSCT) Healthcare workers ( $\mathrm{n}=195)$, and Northern Ireland Blood Transfusion

136 Service (NIBTS, $n=184$ ) through convalescent plasma programs.

137

138 Pre-pandemic samples (prior to June 2019, $\mathrm{n}=136$ ) were obtained from Ulster

139 University ethics committee approved studies with ongoing consent and from NIBTS

$140(n=200$, more than 3 years old). Plasma samples were used at no more than 3 freeze-

141 thaw cycles for all analyses reported within this manuscript.

142

\section{Clinical information}

144 Basic demographic information and data with regard to probable or definite prior 145 infection with SARS-CoV-2 virus was obtained from PANDEMIC study participants 146 through the secure online questionnaire requiring responses about positive RT-PCR

147 result and/or time from symptom onset. Anonymised participant samples from USA,

148 SHSCT and NIBTS were provided with age, gender and time since PCR-positive, 149 where a previous test had been carried out.

\section{Laboratory-based immunoassays}

152 Details of laboratory immunoassays are summarised in supplementary methods and 153 Table S1.

UK-RTC AbC-19 LFIA

UK-RTC AbC-19 testing was conducted at Ulster University according to manufacturer's instructions (details in Table S1). Assays were performed as cohorts, with samples in batches of 10 , with one researcher adding $2.5 \mu \mathrm{L}$ of plasma to the assay and a second adding $100 \mu \mathrm{L}$ of buffer immediately following sample addition. 
medRxiv preprint doi: https://doi.org/10.1101/2020.09.29.20201509; this version posted November 19, 2020. The copyright holder for this preprint (which was not certified by peer review) is the author/funder, who has granted medRxiv a license to display the preprint in All rights reserved. No reuse allowed without permission.

160 After 20 minutes, the strength of each resulting test line was scored from $0-10$

161 according to a visual score card (scored by 3 researchers; Figure S2). A score $\geq 1$ was

162 positive. Details of samples used for analysis for detection of antibodies are available 163 in Supplementary methods.

\section{Statistical analysis}

166 As per Daniel (9) a minimum sample size based on prevalence can be calculated

167 using the following formula: $n=\frac{Z^{2} P(1-P)}{d^{2}}$, where $\mathrm{n}=$ sample size, $\mathrm{Z}=\mathrm{Z}$ statistic for a chosen level of confidence, $P=$ estimated prevalence, and $d=$ precision. Assuming a prevalence of SARS-CoV-2 of $10 \%$ and a precision of $5 \%$, we estimate that the

170 required sample size at $99 \%$ confidence $(Z=2.58)$ to be 240 individuals. If the true

171 prevalence is lower, $5 \%$, the estimated required sample size given a precision of

$1722.5 \%$ is 506 individuals. A minimum sample size of 200 known positives and 200

173 known negatives is given within MHRA guidelines for SARS-CoV-2 LFIA antibody

174 immunoassays(10).

175 Statistical analysis was conducted in in $\mathrm{R} v$ 4.0.2(11). To assess discordance between

176 test results, data was first filtered to include individuals with an Abbott test result in the

177 range $\geq 0.25 \& \leq 1.4$, with a $2 \times 2$ contingency table produced that comprised all 178 possible combinations of [concordant|discordant] test results [within|outside of] this 179 range. A p-value was derived via a Pearson $x^{2}$ test after $2000 p$-value simulations via 180 the stats package.

181 AbC-19 LFIA performance analyses were performed using MedCalc online (MedCalc

182 Software, Ostend, Belgium). ROC analysis was performed via the $\mathrm{pROC}$ package. To 183 compare test result (Positive|Negative) to age, a binary logistic regression model was 184 produced with test result as outcome - a p-value was then derived via $x^{2}$ ANOVA. To 
medRxiv preprint doi: https://doi.org/10.1101/2020.09.29.20201509; this version posted November 19, 2020. The copyright holder for this preprint (which was not certified by peer review) is the author/funder, who has granted medRxiv a license to display the preprint in All rights reserved. No reuse allowed without permission.

185

186

187

188

189

\section{Results}

191 We analysed samples from a mixed cohort of individuals from the general public 192 ( $n=279)$, Northern Ireland healthcare workers $(n=195)$, pre-pandemic blood donations

compare time against test result (encoded continuously), a linear regression was performed. We calculated median per time-period and then converted these to log [base 2] ratios against the positivity cut-off for each assay. All plots were generated via ggplot2 or custom functions using base $\mathrm{R}(12)$. and research studies $(n=223)$ and through a convalescent plasma program $(n=183)$. Antibody levels in plasma from these 880 individuals were assessed using the three SARS-CoV-2 immunoassays; Eurolmmun $\lg G$, Roche Elecsys $\lg G / \operatorname{lgM} / \lg A$ and Abbott Architect IgG (Table S1). This included a cohort of 223 pre-pandemic plasma samples collected and stored during 2017 to end of May 2019 to determine assay specificity. Of the 657 participants whose samples were collected during the pandemic, 265 (40.33\%) previously tested RT-PCR positive with a range of 7-173 days since diagnosis. A total of 225 participants gave time since self-reported COVID19 symptoms, with a range of 5-233 days from symptom onset, whilst 198 had no symptom or PCR data available.

\section{Laboratory based antibody immunoassays}

A positive result for antibody on one or more of the three laboratory immunoassays was recorded for $385 / 657$ (58.6\%) participants who provided a sample during the pandemic. By Eurolmmun ELISA, 346 were positive, 20 borderline and 291 were negative. The Roche assay detected 380 positive and 277 negative, whilst Abbott 
medRxiv preprint doi: https://doi.org/10.1101/2020.09.29.20201509; this version posted November 19, 2020. The copyright holder for this preprint (which was not certified by peer review) is the author/funder, who has granted medRxiv a license to display the preprint in All rights reserved. No reuse allowed without permission.

determined 310 positive and 347 negative (Table S2). The median age across all age groups combined was lower for participants testing positive across each of the immunoassays (median [sd] for positive versus negative, respectively: Eurolmmun, 41 [13.16] vs 48 [12.95]; Roche, 42 [13.08] vs 48 [13.00]; Abbott, 41 [13.18] vs 47 [13.09]). (Figure S3, $\mathrm{p}<0.0001$ ). When segregated by age group, however, differences were less apparent in certain groups (Figure S4). Excluding the pre-pandemic cohort, this gap reduced but remained statistically significant Eurolmmun, 41 [13.18] vs 45 [12.49]; Roche, 42 [13.15] vs 45 [12.49]; Abbott, 41 [13.26] vs 44 [12.63]) $(p<0.01)$ (median [sd] for positive versus negative). Of note, out of 265 individuals with a previous positive RT-PCR result for SARS-CoV-2 viral RNA, 14 (5.2\%) did not show detectable antibodies by any of the three immunoassays, with no association found with age, gender or time between test and blood draw (data not shown).

The three commercial laboratory immunoassays provide a ratio value that increases with IgG antibody titre. When correlation between these values is assessed, good overall agreement is observed between the three immunoassays (Figure 1, Figure S5). As highlighted by Rosadas et al., we also see significant disagreement in the Abbott 0.25-1.4 range when compared to Eurolmmun and Roche (Figure 1a,b; chisquare $p$-values: Eurolmmun vs Abbott, $p<0.001$; Roche vs Abbott, $p<0.001)(13)$.

\section{Duration of humoral response to SARS-CoV-2}

We found IgG antibodies could still be detected in individuals (excluding prepandemic) across all three immunoassays used up to week 20 (day 140) (Figure 2). We note a statistically significant decrease in signal with respect to time across each assay ( $p$-value [slope]): Eurolmmun, $p=0.036$ [-0.785]; Roche, $p=0.002$ [-0.125]; Abbott, $p<0.0001$ [-3.585]. These remained statistically significant after adjustment 
medRxiv preprint doi: https://doi.org/10.1101/2020.09.29.20201509; this version posted November 19, 2020. The copyright holder for this preprint (which was not certified by peer review) is the author/funder, who has granted medRxiv a license to display the preprint in All rights reserved. No reuse allowed without permission.

234 for age. Antibody levels (expressed as a ratio of median result per timepoint divided

235 by positivity cut off; Figure 2d) peaked at Week 1-2 for Eurolmmun (1.33) and Abbott

236 (1.64), though reached highest levels at Week 8-12 when measured by Roche

237 (5.45). By week 21-24, median score for all tests had dropped below the positivity

238 cut off, though a small number of RT-PCR positive samples remained above the

239 positive cut off at these later timepoints (Figure 2).

240

UK-RTC AbC-19

242 Using the commercial immunoassays described we established a well characterised

243 serology sample set of 'known positive' and 'known negative' for IgG antibodies to

244 SARS-CoV-2 to evaluate performance metrics for the UK-RTC AbC-19 Rapid LFIA.

245 AbC-19 detects IgG antibodies against the spike protein antigen, so we therefore 246 required all samples to be positive by the Eurolmmun SARS-CoV-2 IgG ELISA, which

247 likewise detects antibodies against the S1 domain (14). To develop this characterised

248 cohort, samples were also required to be positive by a second immunoassay (Roche

249 or Abbott). To analyse specificity of the AbC-19 LFIA for detection of SARS-CoV-2 IgG

250 antibody, we assessed 350 plasma samples from participants classed as 'known negative for SARS-CoV-2 IgG antibody' on the AbC-19 LFIA. All samples were from

252 individuals confirmed to be negative across all three laboratory assays (Roche,

253 Eurolmmun, Abbott). Using these positive $n=304$ and negative $n=350$ antibody

254 cohorts, we determined a sensitivity for detecting SARS-CoV-2 IgG antibody of

$25597.70 \%(95 \% \mathrm{Cl} ; 95.31 \%-99.07 \%)$ and specificity of $100 \%(98.95 \%-100.00 \%)$ for the

256 AbC-19 LFIA (Table 1).

257 Given a recent report of lower specificity in the AbC-19 LFIA (15) and the possibility 258 of introducing sample bias, we revised our inclusion criteria for the negative cohort. 
medRxiv preprint doi: https://doi.org/10.1101/2020.09.29.20201509; this version posted November 19, 2020. The copyright holder for this preprint (which was not certified by peer review) is the author/funder, who has granted medRxiv a license to display the preprint in

All rights reserved. No reuse allowed without permission.

259 For the pre-pandemic cohort, we included samples from all 223 individuals,

260 regardless of results on other laboratory immunoassays. When this assumed

261 negative pre-pandemic cohort was used for laboratory evaluation for target condition

262 of antibodies, we observed a specificity of $99.55 \%(97.53 \%$ to $99.99 \%$, Table 1$)$. We

263 obtained more AbC-19 devices and expanded the negative cohort to include all

264 samples that matched our criteria (samples collected during the pandemic to be negative by all three laboratory assays and all pre-pandemic samples regardless of other immunoassay results). The specificity observed on this extended negative cohort of 488 samples was $99.59 \%(98.53 \%$ to $99.95 \%$, Table 1$)$. For sensitivity analysis on a positive cohort (samples positive by Eurolmmun and one other test), we were able to analyse all samples previously untested due to limited testing capacity and tested a positive cohort of 330 samples giving a sensitivity of $97.58 \%$ (95.28\% to $98.95 \%$, Table 1$)$.

273 When used for its intended use case, the AbC-19 LFIA provides binary 274 positive/negative results. However, when assessing LFIA in the laboratory, each test line was scored against a scorecard by three independent researchers ( 0 negative, 1 10 positive; Figure S2). Compared to quantitative outputs from the Abbott, Eurolmmun and Roche assays, the AbC-19 LFIA shows good correlation (Abbott $r=0.84[p<0.001]$;

278 Eurolmmun $r=0.86[p<0.001]$; Roche $r=0.82$ [p<0.001]; Figure 3, Figure S5-Figure S7).

\section{Analytical specificity and sensitivity of AbC-19 LFIA}

281 We observed no cross-reactivity across samples with known H5N1 influenza,

282 Respiratory syncytial virus, Influenza A, Influenza B, Bordetella Pertussis, 283 Haemophilus Influenzae, Seasonal coronavirus NL63 and 229E on the AbC-19 LFIA 
medRxiv preprint doi: https://doi.org/10.1101/2020.09.29.20201509; this version posted November 19, 2020. The copyright holder for this preprint (which was not certified by peer review) is the author/funder, who has granted medRxiv a license to display the preprint in All rights reserved. No reuse allowed without permission.

284 ( $n=34$ samples, $n=8$ distinct respiratory viruses; Table S3). Against a panel of external reference SARS-CoV-2 serology samples, the AbC-19 LFIA detected antibodies with scores commensurate to the Eurolmmun ELISA scores (Figure S8, Table S4).

\section{Discussion}

289 Serological antibody immunoassays are an important tool in helping combat the SARS-CoV-2 pandemic. One difficulty faced in validation of antibody diagnostic assays has been access to samples with known SARS-CoV-2 antibody status. As previously described, there is no clear gold standard for reference against which to assess SARS-CoV-2 immunoassays. A positive RT-PCR test has been used previously to indicate previous COVID-19 infection, though this approach is limited by a high rate of false negatives, failure in some cases to develop IgG antibodies (serosilence or lack of antibody against the same antigenic component of the virus as the immunoassay uses as a capture antigen) and the lack of RT-PCR testing availability early in the pandemic $(3,5,16)$. We failed to detect SARS-CoV-2 IgG antibody in 14 of $265(5.2 \%)$ of previously RT-PCR SARS-CoV-2 viral RNA positive participants in this study. It is unclear if this is due to insufficient/absent antibody production in these individuals, or due to a false positive PCR result which may occur in the UK at a rate between $0.8-4.0 \%$ (17). Self-assessment of symptoms for COVID-19 disease is a

303 poor indicator of previous infection, even amongst healthcare workers (18).

304 Asymptomatic individuals may be unaware of infection and others may harbour preexisting immunity or elucidate a T cell response. Additionally, the kinetics of a SARSwith time, contributing to false negative RT-PCR test results for individuals who may

308 be late to present for virus detection tests $(5,19)$. 
medRxiv preprint doi: https://doi.org/10.1101/2020.09.29.20201509; this version posted November 19, 2020. The copyright holder for this preprint (which was not certified by peer review) is the author/funder, who has granted medRxiv a license to display the preprint in All rights reserved. No reuse allowed without permission.

310 Our results show strong correlation between all three immunoassays, with

311 shortcomings in the Abbott system output 0.25-1.4 range, as described previously,

312 suggesting an overestimated positive cut-off (Figure 1) (13). Our detection of

313 antibodies 140 days after RT PCR positive status (20 weeks, and beyond in a small

314 number of samples) indicates persistence IgG antibodies to both the spike protein

315 and nucleocapsid protein, despite typical patterns of antibody decay after acute viral

316 antigenic exposure being as rapid (20). Others have reported SARS-CoV-2

317 antibodies decline at 90 days (19), we also noted a statistically significant decline

318 over time but levels remain detectable at 140 days (Figure 2). We note that IgG

319 levels reach their peak (Roche ratio 5.45 times threshold cut-off) as late as Week 8-

32012 from first symptoms or a viral RNA RT-PCR positive result, though this may be an

321 artefact of lower number of participants at earlier timepoints (Figure 2d). Longitudinal

322 studies on SARS-CoV-1 convalescent patients suggests that detectable IgG can still

323 be present as long as 2 years after infection (21). Further studies are needed on

324 large cohorts with sequential antibody immunoassays performed on symptomatic and non-symptomatic individuals as well as those with mild or severe COVID-19 to fully elucidate the humoral immune response to SARS-CoV-2. This is vital to inform

327 vaccine durability, so-called 'immune passports' and in the definition of a protective

328 threshold for anti-SARS-CoV-2 antibodies.

329 To assess sensitivity and specificity of the AbC-19 LFIA for its ability to detect SARS-

330 CoV-2 antibody in a laboratory evaluation, we developed a reference standard for

331 SARS-CoV-2 antibodies, which does not rely on a single test as reference. A similar 332 approach was used in a recent seroprevalence study in Iceland, whereby two positive 
medRxiv preprint doi: https://doi.org/10.1101/2020.09.29.20201509; this version posted November 19, 2020. The copyright holder for this preprint (which was not certified by peer review) is the author/funder, who has granted medRxiv a license to display the preprint in All rights reserved. No reuse allowed without permission.

antibody results were required to determine a participant sample as positive for SARS-

334 CoV-2 antibody (16).

335 Our evaluation of performance metrics for the UK-RTC AbC-19 LFIA to detect

336 antibodies for SARS-CoV-2 gave $97.58 \%$ sensitivity and $99.59 \%$ specificity. In a

337 recent evaluation of the AbC-19 tests, Mulchandani et al. observed a specificity of

$33897.9 \%(97.2 \%-98.4 \%)$ on a cohort of pre-pandemic samples and report a sensitivity

339 of $92.5 \%(88.8 \%$ to $95.1 \%)$ for detecting previous infections (based on a previous

340 RT-PCR result) or $84.7 \%(80.6 \%$ to $88.1 \%)$ against the Roche Elecsys antibody test,

341 which detects $\lg \mathrm{M} / \lg \mathrm{g} / \lg$ A SARS-CoV-2 antibodies to the nucleocapsid portion of

342 SARS-CoV-2 (18).

343 In our study, good correlation was observed in quantitative score between results on

344 all immunoassays with the highest observed between Eurolmmun and AbC-19 LFIA

345 (Figure S6, S7). This is to be expected, given both the AbC-19 LFIA and Eurolmmun

346 ELISA detect IgG antibodies against spike protein. For the assessment of immunity to

347 prior natural infection as well as to immunisation, it is important to note $\lg$ G antibodies against SARS-CoV-2 spike protein detected by laboratory-based Eurolmmun ELISA and AbC-19 LFIA are known to correlate with neutralizing antibodies, which may confer future immunity $(22,23)$.

351 Previous evaluations of the sensitivity and specificity reported by Public Health

352 England (PHE), showed a Eurolmmun sensitivity of $72 \%$ and specificity of $99 \%$, Abbott with sensitivity of $92.7 \%$ and specificity of $100 \%$ and Roche with sensitivity of $83.9 \%$ and specificity of $100 \%(24-26)$. The PHE analyses for each of these tests used previous infection (RT-PCR positive status) as a reference standard, the limitations of which are discussed above. 
medRxiv preprint doi: https://doi.org/10.1101/2020.09.29.20201509; this version posted November 19, 2020. The copyright holder for this preprint (which was not certified by peer review) is the author/funder, who has granted medRxiv a license to display the preprint in All rights reserved. No reuse allowed without permission.

358 In the use of characterised 'known positive' and 'known negative' cohorts, one

359 limitation of this study is its potential for spectrum bias, whereby our positive-by-two

360 reference system may artificially raise the threshold for positive sample inclusion,

361 possibly resulting in the overestimation of the sensitivity of any test evaluated (27).

362 However, similar issues have been raised when using previous RT-PCR result or

363 definitive COVID-19 symptoms as inclusion criteria given these will likely skew a

364 cohort towards more severe disease (5). Importantly, our mixed origin of samples

365 forming the cohort provides a positive cohort for assessing assay sensitivity that

366 includes individuals from the general public, healthcare workers and from

367 convalescent plasma programmes. Our analysis of specificity on only pre-pandemic

368 individuals $(\mathrm{n}=223)$ shows similar specificity (99.55\%) to the larger mixed 'known

369 negative cohort' ( $n=488$, sensitivity $99.59 \%)$. In the absence of a clear gold standard

370 test, our system relies on no single test (each with their individual shortcomings) and

371 instead takes an average of three.

372

373 Our assessment of the UK RTC AbC-19 LFIA using our characterised cohorts of

374 known SARS-CoV-2 antibody positive and antibody negative plasma, in a laboratory

375 setting shows good performance metrics for its ability to detect SARS-CoV-2 IgG

376 antibody. We note it uses plasma from venous blood samples, as opposed to the use

377 of a finger prick blood sample. Additionally, when this UK RTC AbC-19 LFIA was used

378 on our cohort, a number of the positive results scored low, (1/10 using the score card

379 under laboratory conditions, Figure 3 ) with a faint test band visible to a trained

380 laboratory scientist but perhaps difficult to identify as positive by individuals performing

381 a single test (Figure S6). This faint line may be reflective of the longer time from

382 infection for the Northern Ireland cohort used. If this AbC-19 LFIA is to be used in 
medRxiv preprint doi: https://doi.org/10.1101/2020.09.29.20201509; this version posted November 19, 2020. The copyright holder for this preprint (which was not certified by peer review) is the author/funder, who has granted medRxiv a license to display the preprint in All rights reserved. No reuse allowed without permission.

clinical settings it is important to determine if all users observe the same results as observed in this laboratory evaluation.

This assessment of the AbC-19 LFIA does not provide data on how this test will perform in a seroprevalence screening scenario, but instead provides metrics for the performance of the test, where presence of SARS-CoV-2 antibodies is of interest, as opposed to previous COVID-19 infection. An important potential use of the AbC-19 LFIA would be in monitoring the immune response to vaccination, with most vaccines utilising SARS-CoV-2 Spike protein antigens (28). It is not yet known if presence of SARS-CoV-2 antibodies indications immunity from infection.

\section{Conclusion}

We present a comprehensive analysis of 880 pre-pandemic and pandemic individuals and show IgG antibodies are detectable up to 140 days from symptoms or positive RT-PCR test, showing persistence of immunity at later time points than previously published. We use antibody positive as an alternative to RT-PCR positive status as a standard for assessing SARS-CoV-2 antibody assays and show strong performance for the UK-RTC AbC-19 LFIA rapid point of care test in detecting SARS-CoV-2 antibodies. It is fully understood that user experience in future studies in the real world is important and may alter the performance characteristics. Also, the effect of operator training will have direct effects upon test performance. We welcome further clinical evaluation of the AbC-19 LFIA in large cohorts of symptomatic and asymptomatic individuals alongside large studies assessing COVID-19 outcomes in individuals with longitudinal studies to fully validate its implementation across all intended use cases. 
medRxiv preprint doi: https://doi.org/10.1101/2020.09.29.20201509; this version posted November 19, 2020. The copyright holder for this preprint (which was not certified by peer review) is the author/funder, who has granted medRxiv a license to display the preprint in

\section{Declarations}

410 Ethics approval and consent to participate

411 All study participants provided informed consent. This study was approved by Ulster

412 University Institutional Ethics committee (REC/20/0043), South Birmingham REC (The

413 PANDEMIC Study IRAS Project ID: 286041Ref 20/WM/0184) and adhered to the

414 Declaration of Helsinki and Good Clinical Practice.

\section{Consent for publication}

416 Not applicable.

\section{Availability of data and materials}

418 The datasets used and/or analysed during the current study are available from the

419 corresponding author on reasonable request.

420 Competing interests:

421 At the time of this study TM and JML acted as advisors to CIGA HealthCare, an

422 industrial partner in the UK Rapid Test Consortium. No personal financial reward or

423 renumeration was received for this advisory role. At the time of submission of this 424 manuscript TM and JML no longer held these advisory positions.

425 All other authors have no potential conflict of interest to report.

\section{Funding:}

427 Costs for assays and laboratory expenses only will be paid by UK-RTC as is normal

428 practice. The authors have not been paid or financially benefitted from this study.

429 The advisory roles within CIGA Healthcare were unpaid temporary roles. This

430 manuscript and associated data within this paper has only been used to build 431 confidence into the overall device design and performance assessment of the UK RTC 
medRxiv preprint doi: https://doi.org/10.1101/2020.09.29.20201509; this version posted November 19, 2020. The copyright holder for this preprint (which was not certified by peer review) is the author/funder, who has granted medRxiv a license to display the preprint in All rights reserved. No reuse allowed without permission.

432 AbC-19 devices and such work was never commissioned for any government

433 contractual consideration.

\section{Authors' contributions:}

$435 \mathrm{TM}, \mathrm{JML}$ conceived the study. LR, JM and TM performed all laboratory analyses. LR, 436 SM and KYN analysed data, KB performed all statistical analyses/interpretations and 437 produced figures. NQ, FJ, GW and PS performed all Roche analyses and provided 438 SHSCT cohort samples. MC, KM and SR performed all Abbott analyses and 439 provided Blood Transfusion cohort samples. TM, RP and AN coordinated participant 440 recruitment, consent and sampling. WB and JML developed online consent forms,

441 questionnaires and databases. LR, JM, AK, AA, GW, DH, SS, CCS performed 442 sample collection and processing. LR and TM wrote the manuscript, with significant 443 contributions from JM and KB. All authors reviewed and approved the final 444 manuscript.

Acknowledgements: We are extremely grateful to all the people of Northern Ireland who took part in this study and gave blood during the pandemic. We are indebted to the phlebotomists- Geraldine Horrigan and Pamela Taylor who conducted the blood draws whilst ensuring the highest possible level of safety to the participants. We are also grateful to Kingsbridge Private Hospital Group for sponsorship and providing everything needed for blood collection including the clinical rooms. We acknowledge Dr Tony Byrne for use of his laboratory and Professor Gareth Davison for laboratory space and equipment during the pandemic within a locked down University. 
medRxiv preprint doi: https://doi.org/10.1101/2020.09.29.20201509; this version posted November 19, 2020. The copyright holder for this preprint (which was not certified by peer review) is the author/funder, who has granted medRxiv a license to display the preprint in All rights reserved. No reuse allowed without permission.

457 1. World Health Organisation. Rolling updates on coronavirus disease (COVID19) [Internet]. 2020 [cited 2020 Aug 11]. Available from: https://www.who.int/emergencies/diseases/novel-coronavirus-2019/events-asthey-happen

2. Lu R, Zhao X, Li J, Niu P, Yang B, Wu H, et al. Genomic characterisation and epidemiology of 2019 novel coronavirus: implications for virus origins and receptor binding. Lancet. 2020 Jan 30;395.

3. Petherick A. Developing antibody tests for SARS-CoV-2. Lancet [Internet]. 2020 Apr 4 [cited 2020 Sep 12];395(10230):1101-2. Available from: https://www.thelancet.com/journals/lancet/article/PIIS0140-6736(20)30788-

4. Winichakoon P, Chaiwarith R, Liwsrisakun C, Salee P, Goonn A, Limsukon A, et al. Negative nasopharyngeal and oropharyngeal swabs do not rule out COVID-19. Vol. 58, Journal of Clinical Microbiology. American Society for Microbiology; 2020.

5. Watson J, Richter A, Deeks J. Testing for SARS-CoV-2 antibodies. BMJ [Internet]. 2020;370. Available from:

6. Black JRM, Bailey C, Przewrocka J, Dijkstra KK, Swanton C. COVID-19: the case for health-care worker screening to prevent hospital transmission. Lancet (London, England) [Internet]. 2020 May 2 [cited 2020 Sep 12];395(10234):1418-20. Available from: http://www.ncbi.nlm.nih.gov/pubmed/32305073

480 7. Petersen LR, Sami S, Vuong N, Pathela P, Weiss D, Morgenthau BM, et al. 
medRxiv preprint doi: https://doi.org/10.1101/2020.09.29.20201509; this version posted November 19, 2020. The copyright holder for this preprint (which was not certified by peer review) is the author/funder, who has granted medRxiv a license to display the preprint in

All rights reserved. No reuse allowed without permission.

persons. Clin Infect Dis [Internet]. 2020 Nov 4; Available from:

483 https://doi.org/10.1093/cid/ciaa1685

484

8. Long Q-X, Tang X-J, Shi Q-L, Li Q, Deng H-J, Yuan J, et al. Clinical and immunological assessment of asymptomatic SARS-CoV-2 infections. Nat Med [Internet]. 2020;26(8):1200-4. Available from: https://doi.org/10.1038/s41591 020-0965-6

9. Daniel WW. Biostatistics : a foundation for analysis in the health sciences. 7th Editio. New York: John Wiley \& Sons, Ltd; 1999. 720 p.

10. Medicines and Healthcare product Regulatory Agency. Target product profile: antibody tests to help determine if people have immunity to SARS-CoV-2 [Internet]. 2020 [cited 2020 Apr 24]. Available from: https://assets.publishing.service.gov.uk/government/uploads/system/uploads/a ttachment_data/file/881162/Target_Product_Profile_antibody_tests_to_help_d etermine_if_people_have_immunity_to_SARS-CoV-2_Version_2.pdf

11. The R Development Core Team. R: A language and environment for statistical computing. ISBN 3-900051-07-0. 2017.

12. Wickham H. ggplot2 Elegant Graphics for Data Analysis. Springer. 2016.

13. Rosadas C, Randell P, Khan M, McClure MO, Tedder RS. Testing for responses to the wrong SARS-CoV-2 antigen? Lancet (London, England) [Internet]. 2020 Sep 5 [cited 2020 Sep 13];396(10252):e23. Available from: http://www.ncbi.nlm.nih.gov/pubmed/32866429

14. UK-RTC and Abingdon Health. Charting the course to a post-COVID world. 2020.

15. Mulchandani R, Jones HE, Taylor-Phillips S, Shute J, Perry K, Jamarani S, et 
medRxiv preprint doi: https://doi.org/10.1101/2020.09.29.20201509; this version posted November 19, 2020. The copyright holder for this preprint (which was not certified by peer review) is the author/funder, who has granted medRxiv a license to display the preprint in All rights reserved. No reuse allowed without permission.

detection of previous SARS-CoV-2 infection in key workers: test accuracy

study. BMJ [Internet]. 2020 Nov 11;371:m4262. Available from:

http://www.bmj.com/content/371/bmj.m4262.abstract

16. Gudbjartsson DF, Norddahl GL, Melsted P, Gunnarsdottir K, Holm H, Eythorsson E, et al. Humoral Immune Response to SARS-CoV-2 in Iceland. N Engl J Med [Internet]. 2020 Sep 1; Available from: https://doi.org/10.1056/NEJMoa2026116

17. Surkova E, Nikolayevskyy V, Drobniewski F. False-positive COVID-19 results: hidden problems and costs. Lancet Respir Med [Internet]. 2020 Nov 11; Available from: https://doi.org/10.1016/S2213-2600(20)30453-7

18. Mulchandani R, Taylor-Phillips S, Jones H, Ades T, Borrow R, Linley E, et al. Self assessment overestimates historical COVID-19 disease relative to sensitive serological assays: cross sectional study in UK key workers. medRxiv [Internet]. 2020 Jan 1;2020.08.19.20178186. Available from:

19. Iyer AS, Jones FK, Nodoushani A, Kelly M, Becker M, Slater D, et al. Persistence and decay of human antibody responses to the receptor binding domain of SARS-CoV-2 spike protein in COVID-19 patients. Sci Immunol [Internet]. 2020 Oct 8;5(52):eabe0367. Available from: http://immunology.sciencemag.org/content/5/52/eabe0367.abstract Three Time Scales: The Dynamics of Plasma Cell and Antibody Populations Illustrated for Hepatitis A Virus. Fraser C, editor. PLoS Comput Biol [Internet]. 2012 Mar 1 [cited 2020 Sep 28];8(3):e1002418. Available from: 
medRxiv preprint doi: https://doi.org/10.1101/2020.09.29.20201509; this version posted November 19, 2020. The copyright holder for this preprint (which was not certified by peer review) is the author/funder, who has granted medRxiv a license to display the preprint in All rights reserved. No reuse allowed without permission.

532 21. Wu L-P, Wang N-C, Chang Y-H, Tian X-Y, Na D-Y, Zhang L-Y, et al. Duration of antibody responses after severe acute respiratory syndrome. Emerg Infect Dis [Internet]. 2007 Oct;13(10):1562-4. Available from: https://pubmed.ncbi.nlm.nih.gov/18258008

22. Iyer AS, Jones FK, Nodoushania A, Kelly M, Becker M, Slater D, et al. Dynamics and significance of the antibody response to SARS-CoV-2 infection. medRxiv [Internet]. 2020 Jan 1;2020.07.18.20155374. Available from: http://medrxiv.org/content/early/2020/07/20/2020.07.18.20155374.abstract

23. Addetia A, Crawford KHD, Dingens A, Zhu H, Roychoudhury P, Huang M, et al. Neutralizing antibodies correlate with protection from SARS-CoV-2 in humans during a fishery vessel outbreak with high attack rate. medRxiv [Internet]. 2020 Jan 1;2020.08.13.20173161. Available from: http://medrxiv.org/content/early/2020/08/14/2020.08.13.20173161.abstract

24. Public Health England. Evaluation of the Abbott SARS-CoV-2 IgG for the detection of anti-SARSCoV-2 antibodies [Internet]. 2020. Available from: https://assets.publishing.service.gov.uk/government/uploads/system/uploads/a ttachment_data/file/890566/Evaluation_of_Abbott_SARS_CoV_2_IgG_PHE.pd

25. Public Health England. Evaluation of the Euroimmun Anti-SARS-CoV-2 ELISA ( $\lg G)$ serology assay for the detection of anti-SARS-CoV-2 antibodies [Internet]. 2020. Available from: https://assets.publishing.service.gov.uk/government/uploads/system/uploads/a ttachment_data/file/893433/Evaluation_of_Euroimmun_SARS_CoV_2_ELISA_ $\lg G_{1}$ 1_.pdf

26. Public Health England. Evaluation of Roche Elecsys AntiSARS-CoV-2 
medRxiv preprint doi: https://doi.org/10.1101/2020.09.29.20201509; this version posted November 19, 2020. The copyright holder for this preprint (which was not certified by peer review) is the author/funder, who has granted medRxiv a license to display the preprint in All rights reserved. No reuse allowed without permission. serology assay for the detection of anti-SARS-CoV-2 antibodies. 2020.

558 27. Hall MK, Kea B, Wang R. Recognising Bias in Studies of Diagnostic Tests Part 1: Patient Selection. Emerg Med J [Internet]. 2019/07/13. 2019 Jul;36(7):4314. Available from: https://pubmed.ncbi.nlm.nih.gov/31302605

561 28. Jeyanathan M, Afkhami S, Smaill F, Miller MS, Lichty BD, Xing Z. Immunological considerations for COVID-19 vaccine strategies. Nat Rev Immunol [Internet]. 2020;20(10):615-32. Available from: https://doi.org/10.1038/s41577-020-00434-6 
medRxiv preprint doi: https://doi.org/10.1101/2020.09.29.20201509; this version posted November 19, 2020. The copyright holder for this preprint (which was not certified by peer review) is the author/funder, who has granted medRxiv a license to display the preprint in All rights reserved. No reuse allowed without permission.

Table 1: UK-RTC AbC-19 LFIA performance metrics against known antibody positive and known antibody negative cohorts.

\begin{tabular}{|c|c|c|c|c|c|c|c|}
\hline $\begin{array}{c}\text { Total } \\
\text { Negative }\end{array}$ & $\begin{array}{c}\text { True } \\
\text { Negative }\end{array}$ & $\begin{array}{l}\text { False } \\
\text { Positive }\end{array}$ & $\begin{array}{c}\text { Total } \\
\text { Positive }\end{array}$ & $\begin{array}{c}\text { True } \\
\text { Positive }\end{array}$ & $\begin{array}{c}\text { False } \\
\text { Negative }\end{array}$ & $\begin{array}{l}\text { Sensitivity } \\
\%(95 \mathrm{Cl})\end{array}$ & $\begin{array}{c}\text { Specificity } \\
\%(95 \mathrm{Cl})\end{array}$ \\
\hline \multicolumn{8}{|c|}{ Pre-pandemic $(n=223)$} \\
\hline 223 & 222 & 1 & $\mathrm{n} / \mathrm{a}$ & $\mathrm{n} / \mathrm{a}$ & $\mathrm{n} / \mathrm{a}$ & $\mathrm{n} / \mathrm{a}$ & $\begin{array}{c}99.55 \% \\
(97.53 \% \text { to } \\
99.99 \%)\end{array}$ \\
\hline \multicolumn{8}{|c|}{ Initially reported cohorts $(n=654)$} \\
\hline 350 & 350 & 0 & 304 & 297 & 7 & $\begin{array}{c}97.70 \% \\
(95.31 \%- \\
99.07 \%)\end{array}$ & $\begin{array}{l}100.00 \% \\
(98.95 \%- \\
100.00 \%)\end{array}$ \\
\hline \multicolumn{8}{|c|}{ Extended cohorts $(n=818)$} \\
\hline 488 & 486 & 2 & 330 & 322 & 8 & $\begin{array}{c}97.58 \% \\
(95.28 \%- \\
98.95 \%)\end{array}$ & $\begin{array}{c}99.59 \% \\
(98.53 \%- \\
99.95 \%)\end{array}$ \\
\hline
\end{tabular}

569

$571 \quad$ Figures

a)

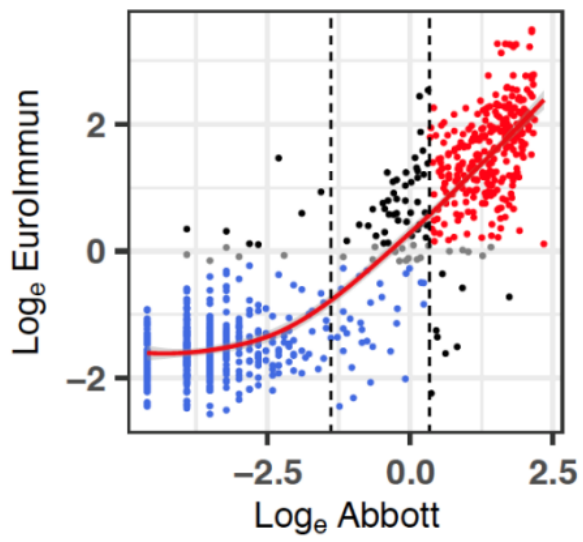

Category

- Both negative

- Both positive

- Disagreement

- Eurolmmun borderline b)

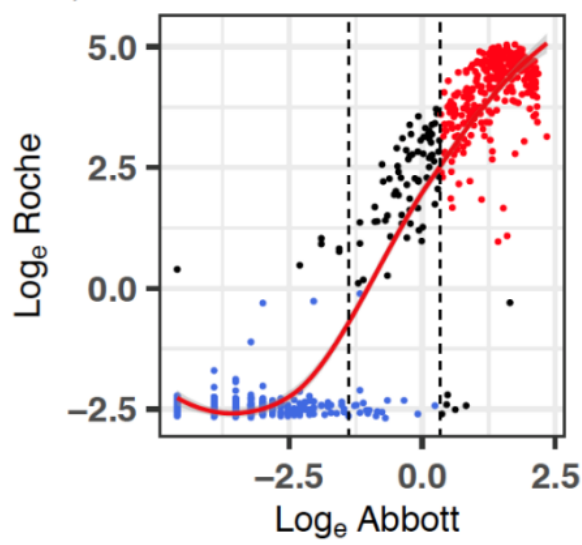

c)

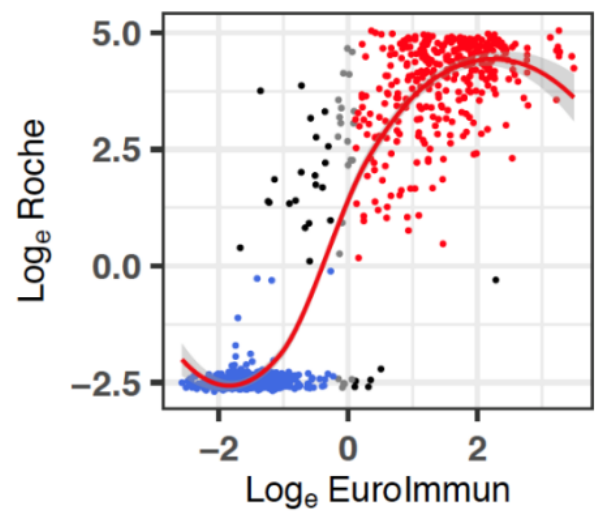

Vit lines, LOESS with $95 \% \mathrm{Cl}$ 
medRxiv preprint doi: https://doi.org/10.1101/2020.09.29.20201509; this version posted November 19, 2020. The copyright holder for this preprint (which was not certified by peer review) is the author/funder, who has granted medRxiv a license to display the preprint in

All rights reserved. No reuse allowed without permission.

576 Figure 1: Two-way correlation scatter plots comparing a) Eurolmmun b) Abbott

577 and c) Roche immunoassays. Pearson $x^{2}$ test was used to assess correlations. The

578 results for each test were log transformed to ensure results follow a normal distribution.

579 Negative agreement shown as blue dots, red dots show positive agreement for the

580 two immunoassays, whilst black dots show disagreement and grey dots as the

581 Eurolmmun borderline results. Vertical lines mark the Abbott test range 0.25-1.4.

$582 \mathrm{n}=880$. The graphs show positive correlations between all immunoassays evaluated,

583 with the fewest disagreement of results between the Log of Roche and the Log of

584 Eurolmmun. Fit lines LOESS, with 95\% confidence interval shaded. 
medRxiv preprint doi: https://doi.org/10.1101/2020.09.29.20201509; this version posted November 19, 2020. The copyright holder for this preprint (which was not certified by peer review) is the author/funder, who has granted medRxiv a license to display the preprint in All rights reserved. No reuse allowed without permission.

a)

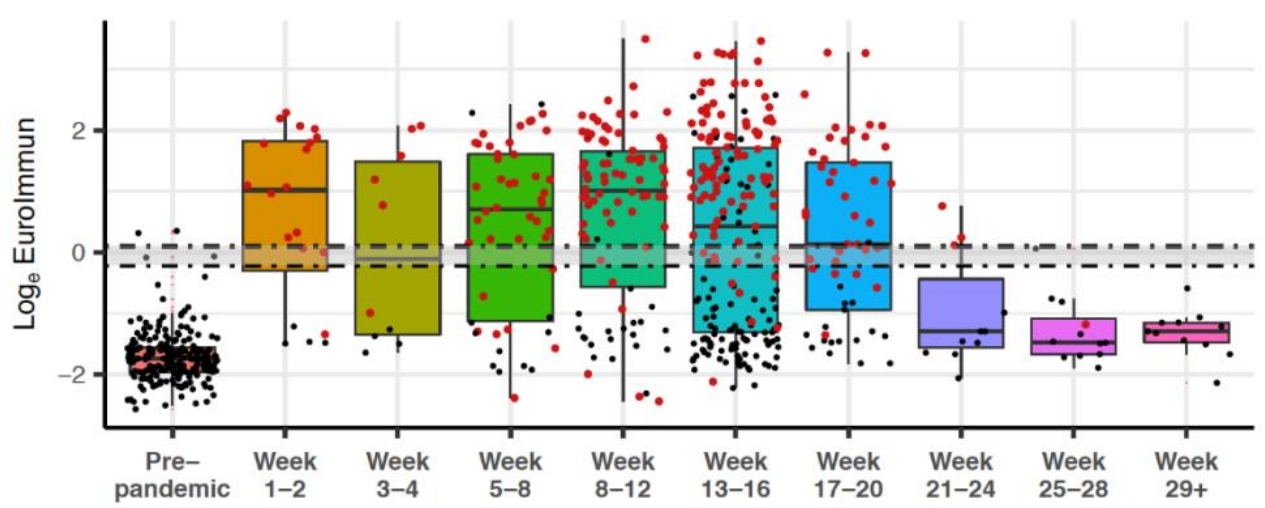

b)

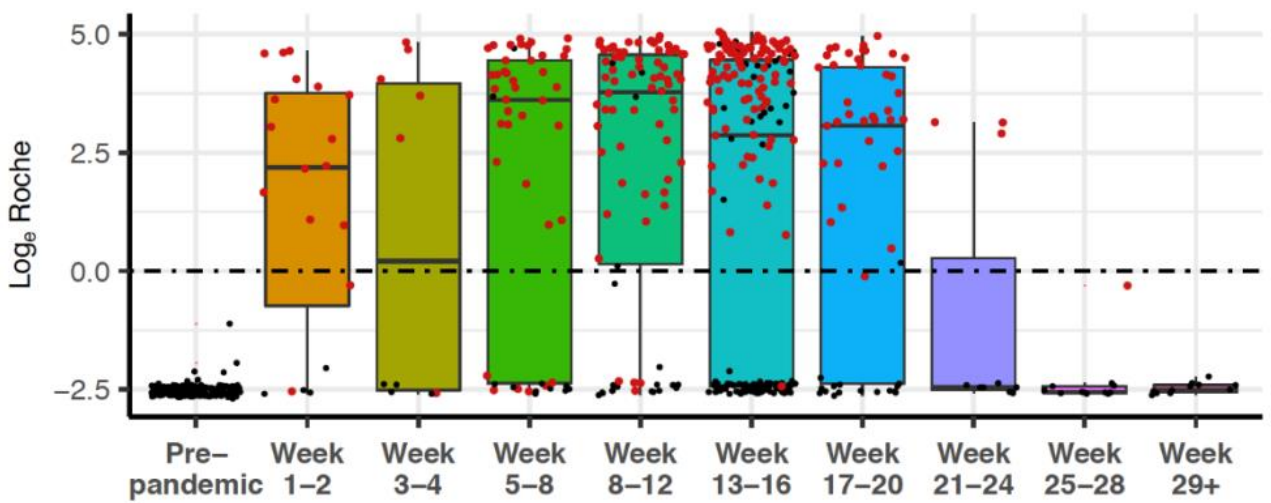

d)

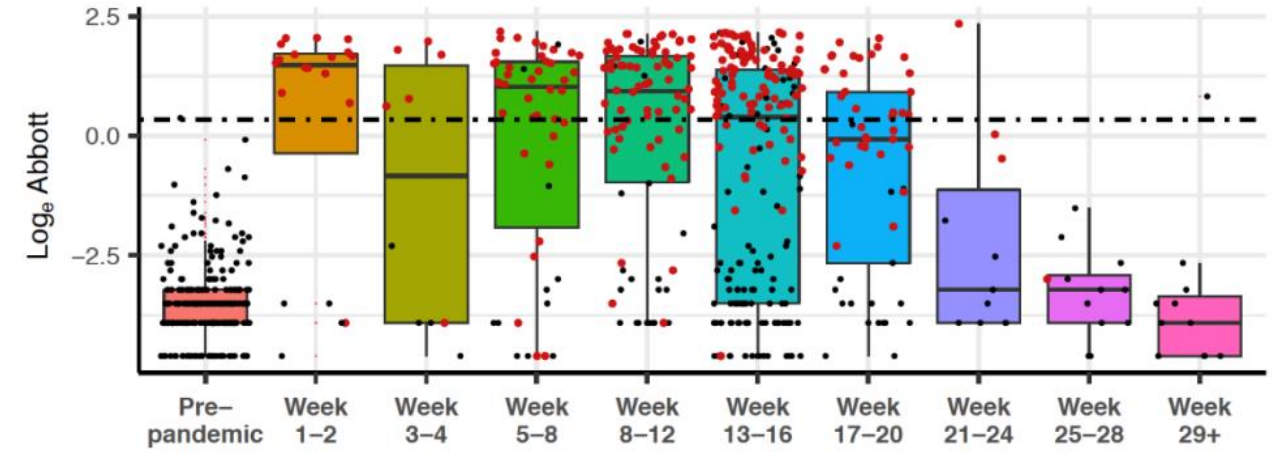

\begin{tabular}{|c|c|c|c|c|c|c|c|c|c|c|}
\hline & \multicolumn{8}{|c|}{ Ratio Antibody level : assay positivity cut-off } \\
\hline & $\begin{array}{c}\text { Pre- } \\
\mathbf{2 0 2 0}\end{array}$ & $\mathbf{1 - 2}$ & $\mathbf{3 - 4}$ & $\mathbf{5 - 8}$ & $\mathbf{8 - 1 2}$ & $\begin{array}{c}\mathbf{1 3 -} \\
\mathbf{1 6}\end{array}$ & $\begin{array}{c}\mathbf{1 7 -} \\
\mathbf{2 0}\end{array}$ & $\begin{array}{c}\mathbf{2 1 -} \\
\mathbf{2 4}\end{array}$ & $\begin{array}{c}\mathbf{2 5 -} \\
\mathbf{2 8}\end{array}$ & $\mathbf{2 9 +}$ \\
\hline Eurolmmun & -2.65 & 1.33 & 0.2 & 0.87 & 1.32 & 0.47 & 0.04 & -2.01 & $-\mathbf{2 . 2 6}$ & $-\mathbf{- 2 . 0 1}$ \\
\hline Roche & -3.64 & 3.16 & 3.05 & 5.21 & 5.45 & 4.14 & 4.42 & -3.54 & -3.69 & -3.61 \\
\hline Abbott & -5.54 & 1.64 & -0.51 & 0.99 & 0.86 & 0.08 & -0.59 & -5.13 & -5.13 & -6.13 \\
\hline $\begin{array}{c}\text { Sample } \\
\text { number } \\
(\mathbf{n}=)\end{array}$ & 223 & 20 & 10 & 50 & 90 & 202 & 53 & 11 & 12 & 11 \\
\hline
\end{tabular}


medRxiv preprint doi: https://doi.org/10.1101/2020.09.29.20201509; this version posted November 19, 2020. The copyright holder for this preprint (which was not certified by peer review) is the author/funder, who has granted medRxiv a license to display the preprint in

All rights reserved. No reuse allowed without permission.

587 Figure 2: SARS-CoV-2 antibody levels by (a) Eurolmmun, (b) Roche, and (c)

588 Abbott, relative to weeks since first reported symptoms or positive PCR result

589 (where data available, $\mathbf{n = 6 8 2 ) . ~ R T - P C R ~ p o s i t i v e ~ i n d i v i d u a l s ~ a r e ~ d e n o t e d ~ b y ~ r e d ~ d o t s , ~}$

590 while individuals with time since symptom data are denoted in black. Dashed lines

591 delineate $\log _{e}$ equivalent of positivity threshold (Eurolmmun 1.1, Roche 1.0, Abbott

592 1.4) for each test, and the negativity threshold for Eurolmmun (0.8; borderline result

593 between the two lines). Black bars indicate median, within IQR (interquartile range)

594 boxes for Eurolmmun/Roche/Abbott value. Red triangles indicate outliers, based on

595 1.5* IQR (interquartile range). (d) Antibody level ratios for assays over time show

596 varying peaks levels depending on test. Calculated by first establishing the median

597 per time period, then calculating log2 ratio for each period versus each respective

598 assay positivity cut-off.

599 
medRxiv preprint doi: https://doi.org/10.1101/2020.09.29.20201509; this version posted November 19, 2020. The copyright holder for this preprint (which was not certified by peer review) is the author/funder, who has granted medRxiv a license to display the preprint in All rights reserved. No reuse allowed without permission.
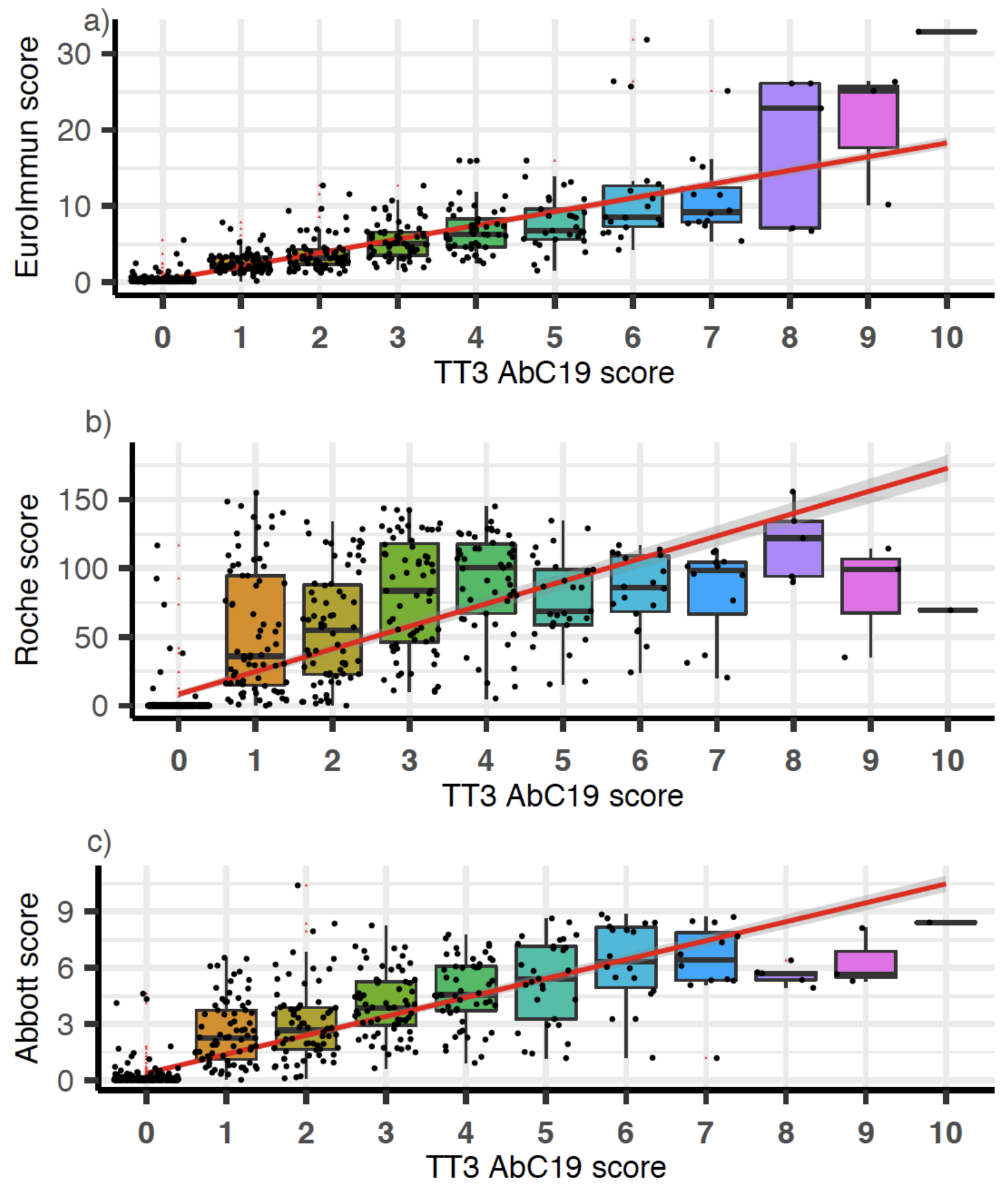
medRxiv preprint doi: https://doi.org/10.1101/2020.09.29.20201509; this version posted November 19, 2020. The copyright holder for this preprint (which was not certified by peer review) is the author/funder, who has granted medRxiv a license to display the preprint in All rights reserved. No reuse allowed without permission.

606 Figure 3: AbC-19 extended cohort ( $n=818)$ correlation to a) Eurolmmun b) Roche

607 and c) Abbott scores. Box plots overlaid on scatter plot, comparing AbC-19 test

608 scores to Eurolmmun, Roche and Abbott quantitative antibody values. Red linear line

609 of best fit with $95 \%$ confidence interval shaded in grey. Black bars indicate median,

610 within IQR (interquartile range) boxes for Eurolmmun/Roche/Abbott value. Red

611 triangles indicate outliers, based on $1.5^{\star}$ IQR (interquartile range). 